\title{
Mineralogical Studies on Some Selected Semi-Precious Stones from Northeast Jordan
}

\author{
Khaled Tarawneh ${ }^{*}$, Hani Alnawafleh ${ }^{2}$, Ibrahim Bani Yasin ${ }^{3}$ \\ ${ }^{1}$ Civil Engineering Department, Engineering Faculty, Amman Arab University, Amman, Jordan \\ ${ }^{2}$ Mining and Mineral Department, Engineering Faculty, Al Hussein Bin Talal University, Ma'an, Jordan \\ ${ }^{3}$ Applied Geology and Environmental Department, Al Albayt University, Mafraq, Jordan \\ Email: *tarrawnehkh@hotmail.com, hani1995@yahoo.com, Ibrahimst@gmail.com
}

How to cite this paper: Tarawneh, K., Alnawafleh, H. and Yasin, I.B. (2020) Mineralogical Studies on Some Selected Semi-Precious Stones from Northeast Jordan. Natural Resources, 11, 168-183.

https://doi.org/10.4236/nr.2020.114011

Received: March 18, 2020

Accepted: April 20, 2020

Published: April 23, 2020

Copyright (c) 2020 by author(s) and Scientific Research Publishing Inc. This work is licensed under the Creative Commons Attribution International License (CC BY 4.0).

http://creativecommons.org/licenses/by/4.0/

\section{Open Access}

\begin{abstract}
A semi-precious stone is known as a gem or gemstone (also a jewel, a gem, a precious stone), which is a portion of mineral in refined and cut form that could be used to create a jewelry or other embellishments. A gem also can be defined as any mineral that is highly prized for its beauty, durability, and rarity, is used for personal adornment and has been enhanced in some manner by altering its shape usually by cutting and polishing. Semi-precious stones occurred as xenolithes are widespread in Jordan within different source of rocks. High grade of copper as malachite and chrysocolla and plancheite is suitable for gemstone manufacture found in Finan area. High purity of garnet can be found in metamorphic rocks in Wadi Araba area, whereas xenoliths of pyroxene, olivine and spinel-perioditite and garnet are wide spread in basalt and pyroclastic materials in northeast Jordan. The studied semi-precious stones are part of the Miocene alkali basaltic rocks that covered the northeastern part of Jordan within Harrat Al-Shaam Basaltic Super Group Plateau concentrated mainly in volcanic centers and volcaniclastic materials of Aritian, Hassan, Ufiyahim and Bishriyya formations. Some of these xenoliths and xenocrysts can be considered as semi-precious stones. This study is focused on characterization of petrography, mineralogy and geochemistry of these semi-precious stones like olivine, pyroxene and garnet xenoliths that have been collected from selected areas in northeast Jordan. The samples were analyzed by polarizing microscope, X-Ray Diffraction (XRD), X-Ray Fluorescence (XRF) and Scanning Electron Microscope (SEM). Cutting and polishing tests have shown that some of the studied xenoliths are suitable for manufacturing attractively colored gemstones and could be considered as semi-precious stones. The geological chances for the discovery of some hundreds of tons of these gemstone-raw materials are considered to be good in volcaniclastic materials that are associated within different volcanic centers at
\end{abstract}


northeast Jordan.

\section{Keywords}

Jordan, Basalt, Xenoliths, Xenocryts, Semi-Precious Stones

\section{Introduction}

Xenoliths of different types of minerals are widespread within Harrat Al-Shaam Basaltic Super Group Plateau at northeast Jordan (Figure 1). This plateau is considered the southern extension of Jebel Ed Drouz Basalt Highlands, and starts about $15 \mathrm{~km}$ east of Mafraq and extends to $160 \mathrm{~km}$ towards east including the study area. The alignment of eruptive vents, the strike of the dykes and the fracture pattern of the area indicate that the fissures had a predominant NW-SE trend [1] [2] [3] [4]. It is evident that lines of structural weakness oriented approximately N-S (Wadi Araba-Dead Sea geosuture), and NW-SE (Red Sea geosuture) were present in areas close to the study area. These structural trends, found in the Proterozoic and earliest Cambrian have been reactivated during the Phanerozoic history of the area and strongly influenced the structural development [1] [5] [6].

Basaltic flows comprise the majority of the study area. The basaltic rocks of

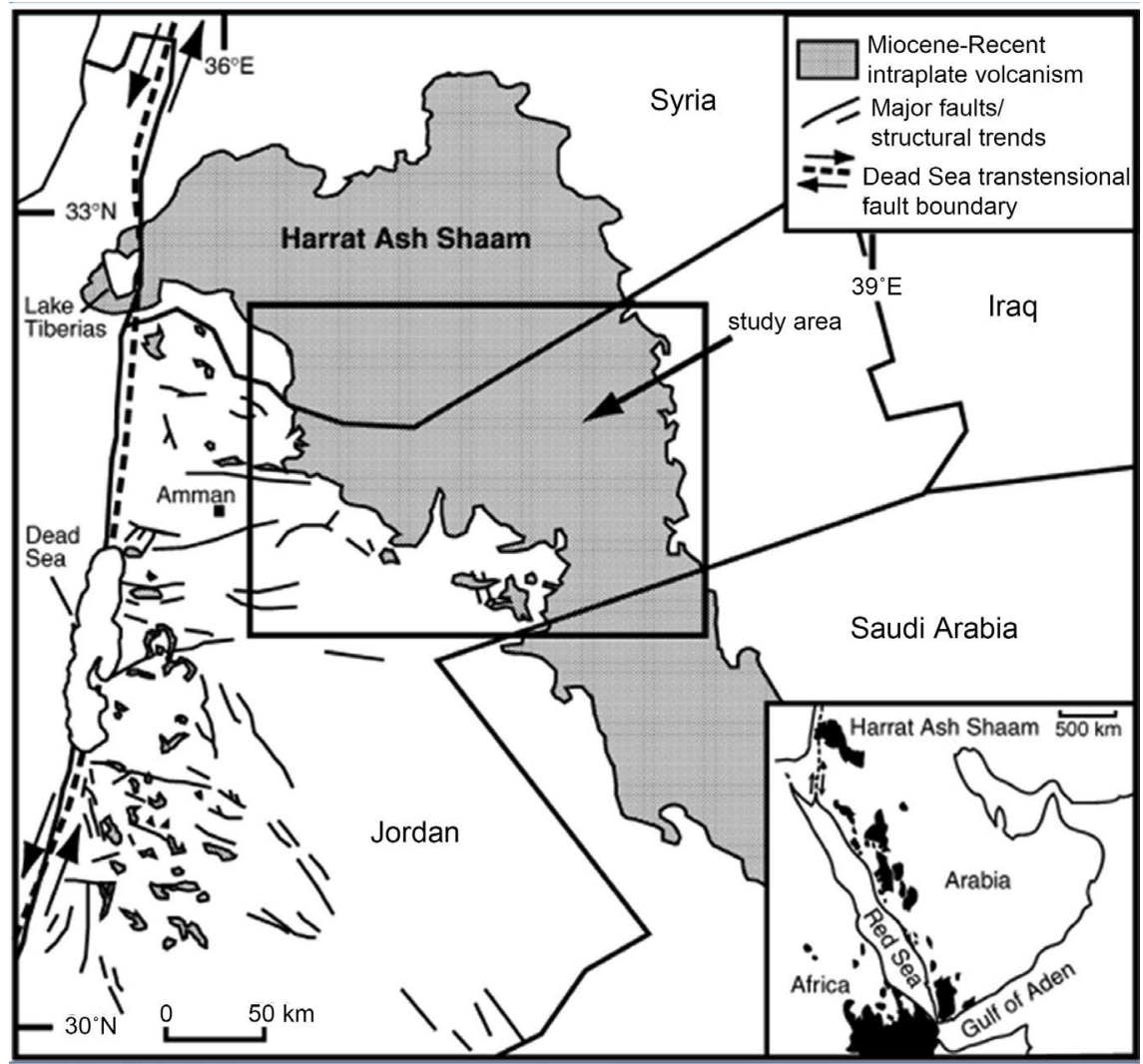

Figure 1. Location map of the study area [7]. 
the Harrat Ash-Shaam Basaltic Super-Group in NE Jordan were subdivided into 5 groups [7]. These are Wisad, Safawi, Asfar, Rimah and Bishriyya groups (Figure 2). Age dating of the basalt in northeast Jordan was carried out during the last years. Results of these studies can be found in [2] [3] [4] [6]. Literature on xenoliths in northeast Jordan can be found in many works, among them [3] [7]-[13]. The maximum recorded thickness of the basaltic succession as recorded in the studied area is about $478 \mathrm{~m}$ [3]. The basalt has a wide variety of crustal and upper mantle xenoliths that have mostly concentrated in pyroclastic materials (Figure 3 \& Figure 4).

The compositional diversity of the xenoliths suit indicates a heterogeneous upper mantle beneath the northwestern part of the Arabian plate. It mainly consists of depleted and later metasomatized spinel iherzolite injected with magmatic veins of pyroxenite [14].

The collected samples of xenoliths considered here as semi-precious stones are concentrated within Asfar, Bishriyya and Rimah, groups, and less commonly within Wisad Group that are exposed in the Harrat Ash Shaam Basalt Super Group [7] (Figure 4). These groups, partially composed of pyroclastic materials included different types of xenoliths and xenocrysts that could be used as semi-precious stones.

This study is focused on characterization of mineralogy, petrography and geochemistry of these semi-precious stone like olivine, pyroxene and garnet xenoliths that have been collected from selected areas in northeast Jordan during geological mapping of the area for the period between 2015 and 2016 as shown in Figure 1.

Selected samples were analyzed by polarizing microscope for thin sections. XRD, XRF and SEM have been carried out to get a better understanding about their mineralogy, petrography, geochemistry, and structural and textural characterization. Cutting and polishing tests have been carried out with aim to get a

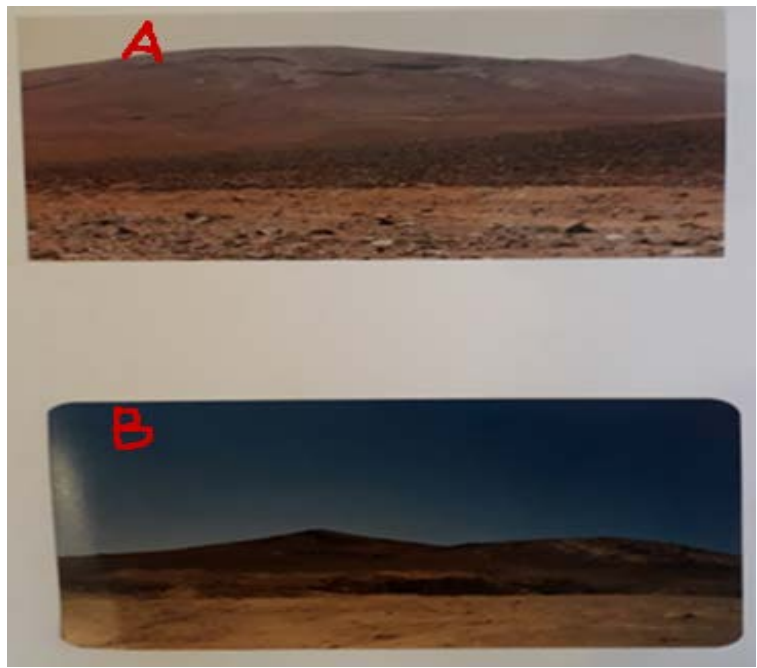

Figure 2. Form of landscape of some volcanic centers in the study area, NE Jordan, (A) represent Aritain Formation; (B) represent Hassan Formation. 


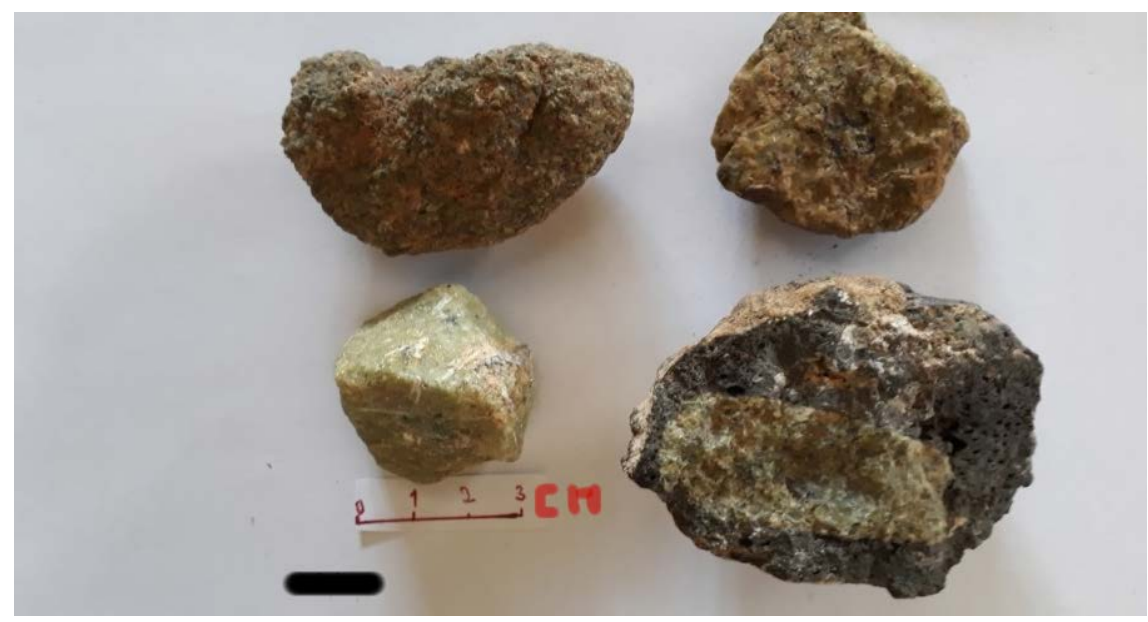

Figure 3. Different forms of xenoliths of olivine as granular or equidimentional or embedded within the soriaceous materials.

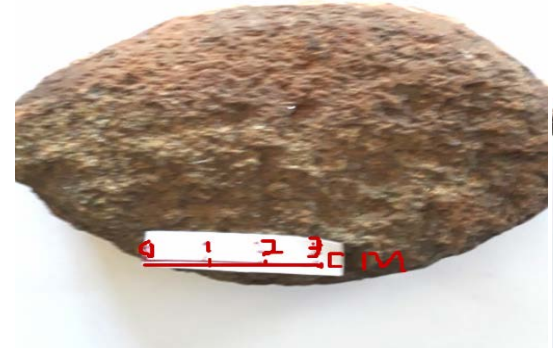

(A)

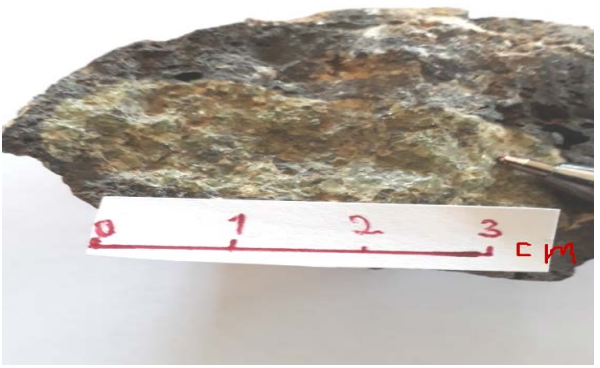

(B)

Figure 4. (A) Rounded Xenoliths of olive brownish green olivine bombs with diameter up to $5 \mathrm{~cm}$ in diameter. (B) Xenolithes of olive green olivine embedded in scoria ( $\mathrm{Al}$ Azraq area, Tell Hassan).

suitable forms for manufacturing attractively colored gemstones that could be used as semi-precious stones depending on their purity and the way of their cutting and polishing. The geological chances for the discovery of some hundreds of tons of gemstone-raw materials are considered to be good in volcaniclastic materials that are associated with Aritian, Hassan, Bishriyya and Ufiyahim formations in northeast Jordan as well in all volcanic centers in Jordan.

\section{Methodology}

Detailed petrographical, mineralogical and geochemical characterization may be productive in finding the characteristics of the xenoliths, which distinguished sources from each other and allow assigning their properties as semi-precious stones. For this purpose twelve samples were collected from different localities and horizons. These horizons are xenolith-rich, particularly in spinel lherzolite and spinel dunite, olivine and pyroxenite. These xenoliths intercalate the pyroclastic rocks and occur as cored bombs. Four samples of garnet, four samples of pyroxene and four olivine samples were studied. Thin sections were prepared examined under Binocular Stereomicroscope and Polarizer microscope at Al Hus- 
sein Bin Talal University (AHU) with aim to identify the petrographic properties of the rock samples. Bulk samples of the xenoliths were analyzed by X-Ray diffraction (XRD) that was performed using SHIMADZU LabX XRD-6100 at the laboratories of AHU. The analyses used to assist in the identification of the mineral present in the xenoliths. For this purpose mineral identification carried out via ICDD PDF-2/Release 2013 RDB and comparison with literature. Sample was crushed the finely ground using lab scale grinding machine. For the X-ray diffraction method, the size and uniformity of sample particles are important in the determination of the diffraction pattern accuracy. The size was reduced to less than 75 microns. A small fraction of the finely ground sample was taken for mounting stage. The sample plate was then placed on the glass plate with the dent in its upward. The powdered sample then filled in it. Sample was then covered with a medicine wrapping paper and pressed down with fingers. The powdered sample fed in such way so that its particles swell slightly from sample plate. Finally, the swell off the sample plate is scrapped with a razor blade. The sample plate was mounted on the goniometer sample holder with the samples upward. The sample plate must be placed roughly in the center of the sample holder.

One sample of garnet, pyroxene and olivine examined using Scanning Electron Microscope (SEM)-FEI, the later utilized a Jeol 840 instrument equipped with a Link 10,000 Energy Dispersive Spectrometry (EDS-System). SEM coupled with back-scattered electron image (BSE-image) and ESM secondary electron image (SE-image). SEM was used to identified the microstructure and investigate the nature of minerals microstructure relationships. The chemical analyses of major elements of the samples were determined on fused glass discs-like pellet (bead), using the SHIMADZU EDX-7000 XRF instrument-Model at AHU. Added two grams powder samples, mixed with 8 grams lithium tetra borate, and fused in platinum crucibles over gas burners $\left(1000^{\circ} \mathrm{C}\right)$ for one hour. Melts poured into a mold creating glass disks. The Loss on Ignition (LOI) was determined by weight lost after melting at $1000^{\circ} \mathrm{C}$. Most of the work lap of the gemstones used by holding the gem between fingertips and carefully polish them on a 1200 grit lap 260 grit lab depend on the gem if it is rough to remove. Next step is to secure the rough surface of gem using warm wax. All samples have been subjected for this purpose.

\section{Results and Discussion}

\subsection{Megascopic Study}

Most of the xenoliths are occurred and scattered in volcanic tuff as a single aggregates or encountered within pyroclastic materials or embedded in basaltic rocks (Figure 5). Their distribution and percentage in the study area varies in all volcanic centers (Figure 2). The high distribution and percentage can be observed in Aritain Volcanic Formation and partially in Hassan Scoriacious, Bishriyya and Ufayhim formations. The most common mineral composition of the 


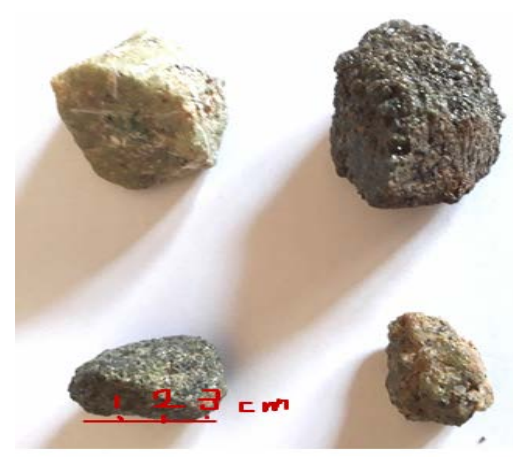

(A)

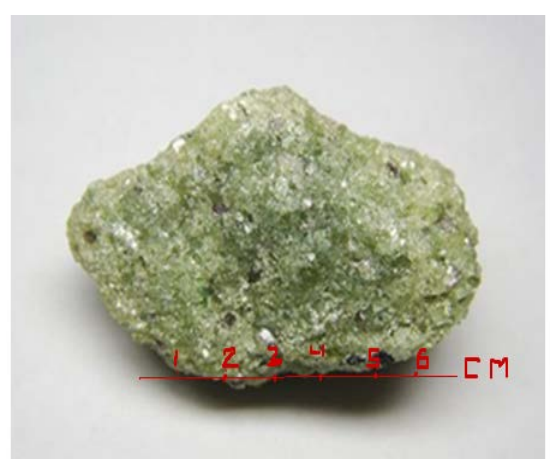

(B)

Figure 5. (A) and (B) Different types of olivine crystals with olive green, yellow green and brownish green color with different sizes.

xenoliths are composed of olivine, orthopyroxene (opx) clinopyroxene (cpx), garnet and spinel. The studied xenoliths showed that it varies in shape and dimensions. Individual grains, coarse grained as phenocrysts or as xenocrysts with oval, prismatic and equigranular form can be observed with range from $1 \times 2 \times 3$ $\mathrm{cm}$ in size (Figures 5-7).

Olivine with granular, oval and orthorhombic shape can be observed, average $1-5 \mathrm{~mm}$ up to $5 \mathrm{~cm}$ in size most common. Volcanic bombs of olivine with up to $10 \mathrm{~cm}$ in diameter can be observed and scattered in basalt or with scoriaceous materials (Figure 4). Olivine with pale green to dark green and pale yellowish to reddish in color is common. Iddingsite can be seen in the hand specimen. Sometimes olivine xenoliths are highly fractured and can be crushed by fingers.

Pyroxene xenoliths are widespread in most pyroclastic materials. Prismatic and elongated shapes of pyroxene are most common. Pyroxene xenolith has size range from 1 to $3 \mathrm{~cm}$ in diameter. Most of the pyroxene like enstatite has good hardness with gray to black and dark green color (Figure 6).

Garnet minerals common as a single crystals and scattered partially and randomly in some of basalt flows. Most of the crystals are euhedral to subhedrall shape with average 0.5 to $1 \mathrm{~cm}$ in diameter with dark brown to red color and slightly fractures (Figure 7).

\subsection{Petrographic Description}

Thin-section analysis showed that the olivine occurs as phenocrysts and xenocrysts. Olivine is fine-grained and slightly altered to iddingsite with prophyritic to equigranular textures. The fresh and green to dark green olivine phenocrysts are clustered and made up of $15 \%-25 \%$ of the basalt (Figure 8).

Intergranular and rarely trachytic, interstitial, porphyritic and amygdaloidal textures are occurs. Plagioclase is the most common phenocryst coexisting with olivine (Figure 9). The pyroxene present as fine-grained, euhedral to subhedral, fractured and poikilitic, augite with brown to pinkish and purple color is common.

The pyroxene made up $20 \%-24 \%$ of the rock. Corona texture is present, 


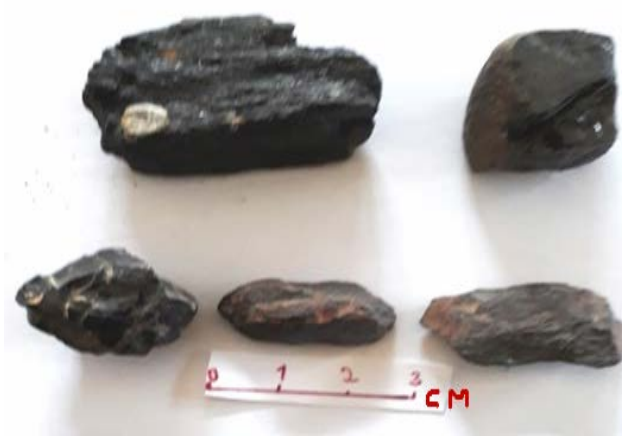

(A)

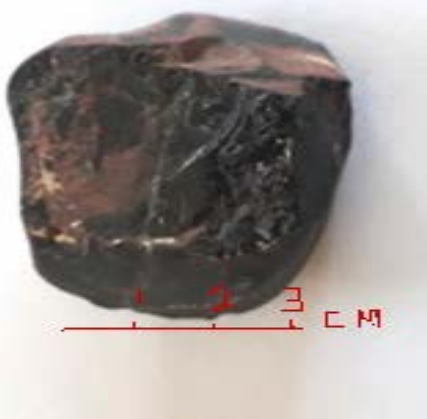

(B)

Figure 6. (A) and (B) Different types of pyroxene crystals with dark brown to black color with different sizes and isometric shape.

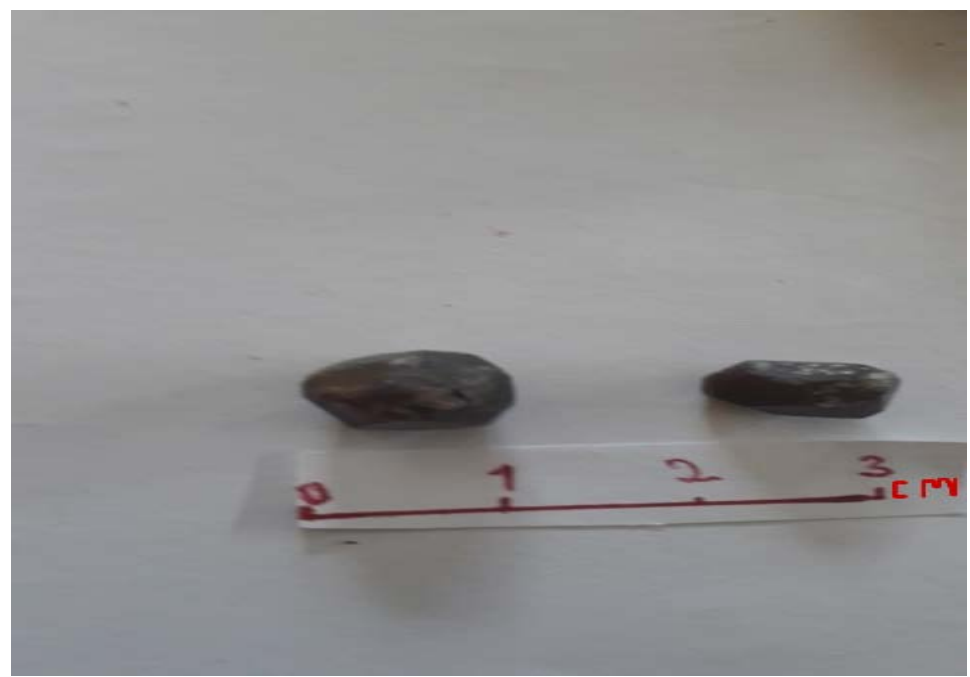

Figure 7. Garnet crystals with dark brown color.

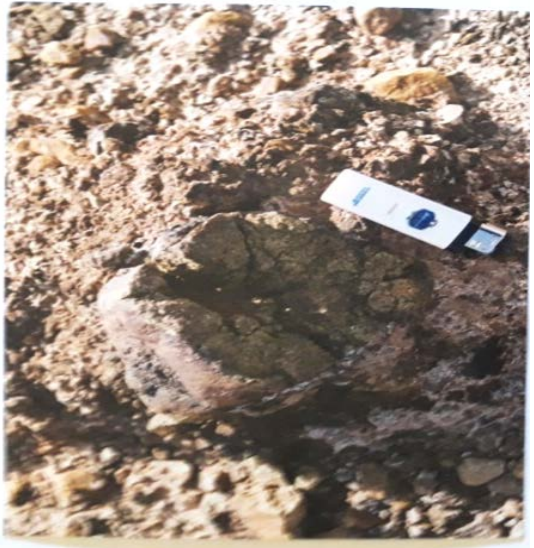

(A)

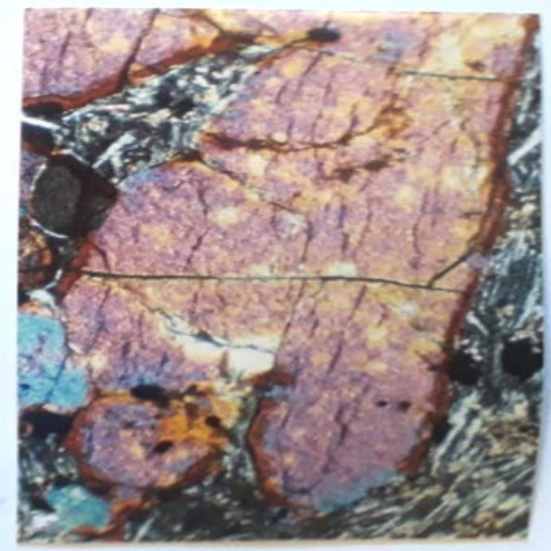

(B)

Figure 8. The left photomicrograph (A) showing derived xenoliths of olivine. The right photomicrograph (B) showing olivine xenocryst surrounding by plagioclase crystals (XPL, 10×). 




(A)

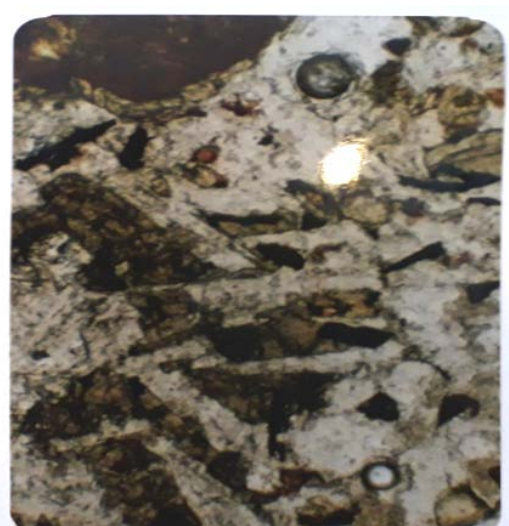

(B)

Figure 9. The left photomicrograph (A) showing xenocrysts of olivine, surrounding by pyroxene and laths of plagioclase (XPL, 20×). The right photomicrograph (B) showing pyroxene xenolith rich in opx and euhedral crystals of garnet (PPL, 10×).

pyroxene surrounded to garnet crystal. These textures formed in reaction between garnet and pyroxene [15]. Other type of corona texture are mad in orthopyroxene surrounded to the garnet crystal, this texture refer to second type of kelyphites texture (radial around garnet). The garnet crystal shows medium grain size, highly fracture, colorless to light color with PPL and dark color with $\mathrm{XPL}$, expect light to gray color of fracture filling with other minerals mostly pyroxene (Figure 10). Almandine garnet, up to $3 \mathrm{~mm}$ in size can be observed as phenocryst in plagioclase groundmasss. The garnet crystals are euhedral to subhedral and they are rounded to subrounded, most of garnet is highly fractured, and has intergrowth with pyroxene

Microcrystalline groundmass consists of olivine, acicular microlites of plagioclase, iddingsitized olivine, and Fe-Ti oxides (Figure 11). Some glassy materials are occurs in the groundmass. Opaque mineral are common in the groundmass or enclosed in other crystals such as olivine and pyroxene. They made up to $5 \%-10 \%$ of the xenoliths.

Petrographic and geochemical data for the lower crustal xenoliths indicate that these xenoliths represent basaltic cumulates crystallized at lower crustal pressures [10] [12].

\subsection{Mineralogy}

\subsubsection{X-Ray Diffraction (XRD)}

Minerals identified by XRD include pyroxene assemblages of calcium-sodium pyroxene as $\mathrm{Ae}=$ Aegirine, $\mathrm{Au}=$ Augite $\mathrm{Om}=$ Omphacite); and magnesium-iron pyroxene as $\mathrm{En}=$ Enstatite) $($ Figure 12, Figure 13). Garnet group include $\mathrm{Al}=$ Almandine. Traces of $\mathrm{Li}=$ Linnaeite, $\mathrm{Be}=$ Berzelianite, and $\mathrm{Ka}=$ Kanoite are present. The olivine samples consist mainly of Fo $=$ Forsterite. Traces of other minerals as $(\mathrm{Az}=$ Azoproite, $\mathrm{La}=$ Laihunite, $\mathrm{Ta}=$ Tassieite $)$ were detected by XRD (Figures 12-14). Regarding Nasir [10] [14] all these minerals reflect to form high pressure and temperature for the upper mantle in the earth depth. 




(A)

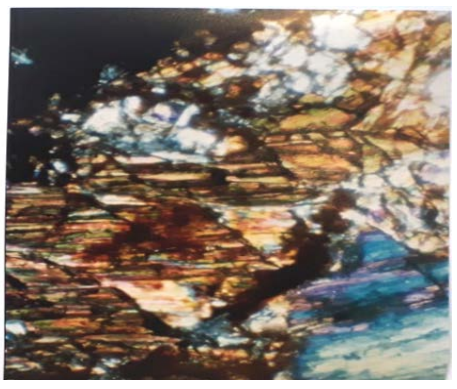

(B)

Figure 10. The left photomicrograph (A) showing phenocrysts of pyroxene and laths of plagioclase (PPL, 10×). The right photomicrograph (B) showing pyroxene xenolith rich in opx, associated with garnet and laths of plagiocalse (XPL, 10×).

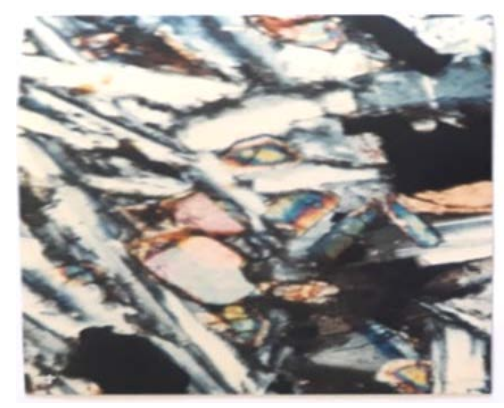

(A)

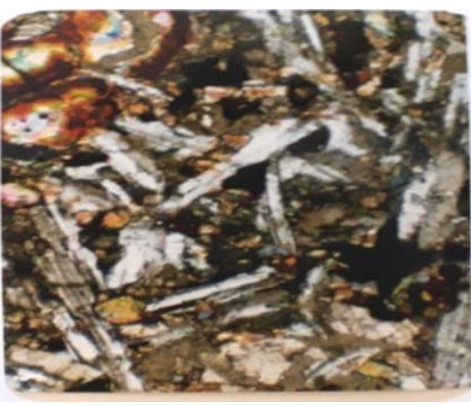

(B)

Figure 11. The left photomicrograph (A) showing xenocrysts of granular pyroxene surrounding by laths of plagioclase and (XPL, 10x). The right photomicrograph (B) showing pyroxene xenolith rich in opx and granular garnet and laths of plagioclase and iddengsite (PPL, 10×).

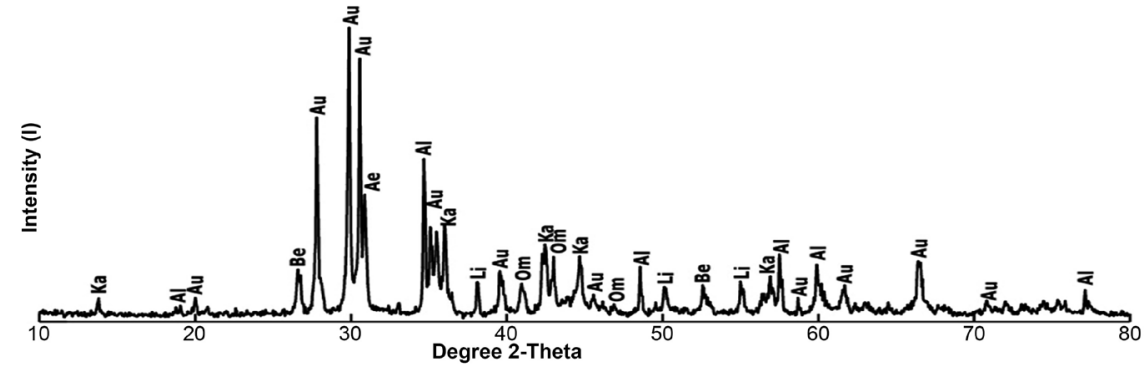

Figure 12. XRD diffractogram for pyroxene sample $(\mathrm{Li}=$ Linnaeite, $\mathrm{Be}=$ Berzelianite, $\mathrm{Al}$ = Almandine, $\mathrm{Ae}=$ Aegirine, $\mathrm{Au}=$ Augite, $\mathrm{Ka}=$ Kanoite, $\mathrm{Om}=$ Omphacite $)$.

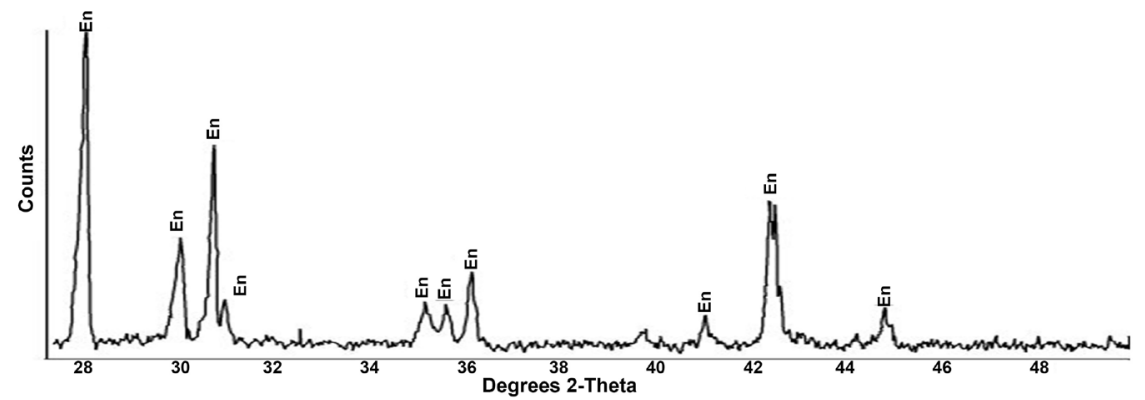

Figure 13. XRD diffractogram for pyroxene sample (En = Enstatite). 


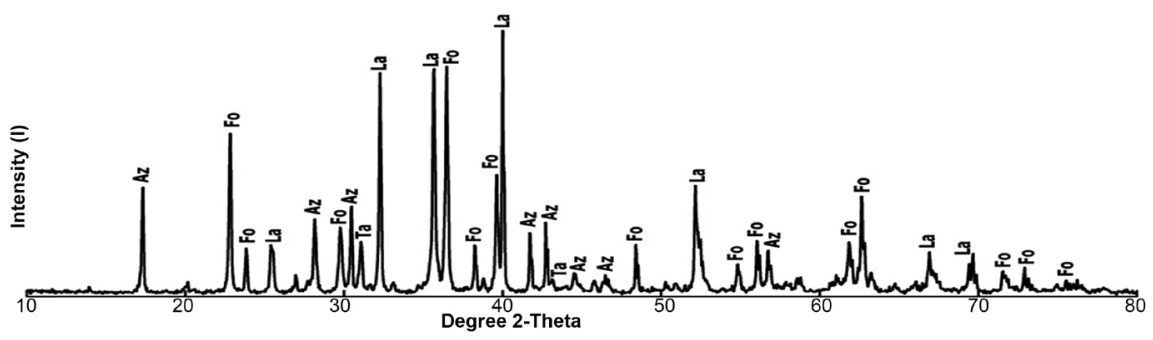

Figure 14. XRD diffractogram for olivine sample $(\mathrm{Az}=$ Azoproite, Fo $=$ Forsterite $\mathrm{La}=$ Laihunite, $\mathrm{Ta}=$ Tassieite).

\subsubsection{Scanning Electron Microscope (SEM)}

Scanning Electron Microscope (SEM) is used to identify and to characterize the textures of the xenoliths. The electron micrographs show that the original of olivine replaced by wadsleyite in the coarse-grained fragments of host rock. The wadsleyite mainly exists the original olivine grain, wadsleyite also occurs along the olivine grain margins, exits as polycrystalline aggregates and occurs along fractures of the original olivine and euhedral olivine (forsterite) crystal (Figure 15(a) \& Figure 15(b)). SEM shows that most of fractures are filling with clinopyroxene, and aggregate of crystal of wadsleyite and platy crystal of jadeite (Figure 15(c) \& Figure 15(d)).

\subsection{Geochemistry}

The content of major oxides in weight $\%$ is given in Table 1 . The chemical analysis of 7 representative samples indicated that the xenoliths have relatively similar amounts of major and minor oxides. On the basis for the major elements of $\mathrm{MgO}$, $\mathrm{Fe}_{2} \mathrm{O}_{3}$ and $\mathrm{CaO}$ content, two samples of the garnet were analyzed. $\mathrm{MgO}$ content is up to $14.93 \%, \mathrm{Fe}_{2} \mathrm{O}_{3}$ content is up to $16.55 \%$, whereas $\mathrm{CaO}$ content is up to $5.88 \%$.

The $\mathrm{Na}_{2} \mathrm{O}$ concentrations is up to $0.27 \%$ in garnet type are similar to the garnet for peridotite and eclogite garnet, whereas the $\mathrm{TiO}_{2}$ content is up to $0.77 \%$ that is similar to the range recorded by Sobolov [16] for garnet from Russia.

The chemical composition of three samples of pyroxene show some variation in the composition of $\mathrm{SiO}_{2}, \mathrm{CaO}, \mathrm{MgO}$ and $\mathrm{Fe}_{2} \mathrm{O}_{3}$, and a relatively similar content of $\mathrm{CaO}(14.47 \%-16.39 \%)$ and $\mathrm{MgO}(10.53 \%-12.40 \%)$, whereas $\mathrm{Fe}_{2} \mathrm{O}_{3}$ ranges from $12.10 \%$ to $20.77 \%$.

The chemical composition of two samples of olivine show small variation in the composition of $\mathrm{SiO}_{2}, \mathrm{CaO}, \mathrm{MgO}$ and $\mathrm{Fe}_{2} \mathrm{O}_{3}$, and a relatively similar content of $\mathrm{CaO}$ up to $2.09 \%$, and $\mathrm{MgO}$ content is up to $41.54 \%$, whereas $\mathrm{Fe}_{2} \mathrm{O}_{3}$ ranges from $12.29 \%$ to $13.27 \%$.

The studied xenoliths relatively have low $\mathrm{SiO}_{2}$ contents of up to $47.73 \%$, and can be classified as ultramafic rather than mafic. They are characterized by high $\mathrm{MgO}$ of up to $41.54 \%, \mathrm{Cr}_{2} \mathrm{O}_{3}$ up to $1.05 \%$ and $\mathrm{NiO}$ content is up to $0.66 \%, \mathrm{Al}_{2} \mathrm{O}_{3}$ content is up to $21.96 \%$, whereas $\mathrm{CaO}$ content is up to $2.09 \%$ in olivine and up to $16.39 \%$ in pyroxene samples. A slightly high $\mathrm{Fe}_{2} \mathrm{O}_{3}$ total content $(12.10 \%$ 20.77\%), accounts for the Fe present in spinel, olivine, pyroxene and opaques [17]. All other minor oxides contents have relatively low concentrations. Their chemical 


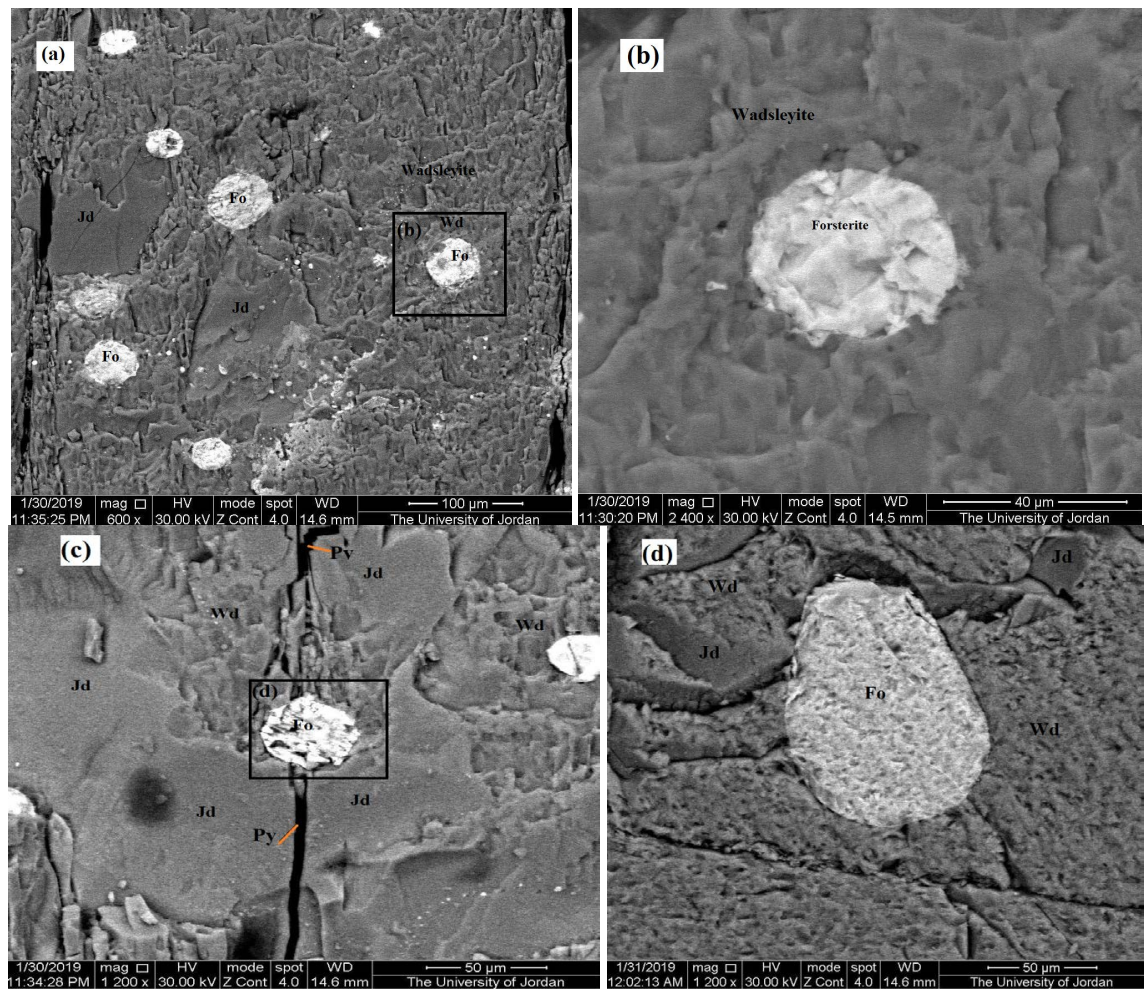

Figure 15. Scanning Electron Microscope Images (a) showing of olivine (forsterite $\mathrm{Mg}_{2} \mathrm{SiO}_{4}$ ), wadsleyite and jadeite. (b) A magnified image of box labeled a in (b), wadsleyite occurs along fractures of the original olivine and Euhedral olivine (forsterite) crystal, (c) Fracture filling with clinopyroxene, and aggregate of crystal of wadsleyite and platy crystal jadeite. (d) A magnified image of box labeled a in (c), shows granular crystal forsterite and platy jadeite (Fo: Forsterite, Wd: Wadsleyite, Ja: Jadeite, Py: Pyroxene).

Table 1. Chemical composition of the xenoliths samples in wt\%.

\begin{tabular}{|c|c|c|c|c|c|c|c|}
\hline Oxide & $\begin{array}{c}\text { Olivine } \\
\text { sample\% }\end{array}$ & $\begin{array}{c}\text { Garnet } \\
\text { sample\% }\end{array}$ & $\begin{array}{l}\text { Pyroxene } \\
\text { sample\% }\end{array}$ & $\begin{array}{c}\text { Olivine } \\
\text { sample\% }\end{array}$ & $\begin{array}{l}\text { Pyroxene } \\
\text { sample\% }\end{array}$ & $\begin{array}{l}\text { Pyroxene } \\
\text { sample\% }\end{array}$ & $\begin{array}{c}\text { Garnet } \\
\text { sample } \%\end{array}$ \\
\hline $\mathrm{MgO}$ & 41.54 & 14.03 & 10.53 & 40.44 & 11.19 & 12.40 & 14.93 \\
\hline $\mathrm{SiO}_{2}$ & 40.86 & 38.37 & 41.76 & 42.77 & 39.89 & 47.73 & 39.37 \\
\hline $\mathrm{Fe}_{2} \mathrm{O}_{3}$ & 13.27 & 15.55 & 20.77 & 12.29 & 18.89 & 12.10 & 16.55 \\
\hline $\mathrm{CaO}$ & 2.07 & 5.69 & 16.39 & 2.09 & 15.98 & 14.47 & 5.88 \\
\hline $\mathrm{SO}_{3}$ & 0.79 & 0.43 & 0.69 & 0.78 & 0.87 & 0.56 & 0.49 \\
\hline $\mathrm{Cr}_{2} \mathrm{O}_{3}$ & 0.70 & 0.33 & 1.05 & 0.79 & 0.76 & 0.89 & 0.39 \\
\hline $\mathrm{NiO}$ & 0.51 & 0.23 & 0.31 & 0.54 & 0.66 & 0.32 & 0.28 \\
\hline $\mathrm{MnO}$ & 0.18 & 0.22 & 0.37 & 0.19 & 0.45 & 0.13 & 0.29 \\
\hline $\mathrm{K}_{2} \mathrm{O}$ & 0.02 & 0.03 & 0.10 & 0.04 & 0.13 & 0.11 & 0.08 \\
\hline $\mathrm{ZnO}$ & 0.01 & 0.03 & 0.01 & 0.02 & 0.04 & 0.05 & 0.07 \\
\hline $\mathrm{TiO}_{2}$ & - & 0.70 & 1.49 & - & 1.33 & 1.23 & 0.77 \\
\hline $\mathrm{Al}_{2} \mathrm{O}_{3}$ & - & 21.96 & 5.43 & - & 8.56 & 9.21 & 19.96 \\
\hline $\mathrm{Na}_{2} \mathrm{O}$ & - & 0.23 & 0.65 & - & 0.55 & 0.37 & 0.27 \\
\hline $\mathrm{P}_{2} \mathrm{O}_{5}$ & - & 0.04 & 0.54 & - & 0.45 & 0.12 & 0.05 \\
\hline Sum & 100.00 & 97.84 & 100.10 & 99.95 & 99.75 & 99.69 & 99.38 \\
\hline
\end{tabular}


range is similar to the average chemical composition of lherzolite of upper mantle origin reported by Thompson [18] [19].

\subsection{Xenoliths as Semi-Precious Stones}

A gemstone is a precious or a semi-precious stone used in jewelry. Gemologists identify gemstones and they considered the gems in the area of gemology using practical language and their features. A gemologist uses the gemstone's chemical arrangement to classify them, and many gems are categorized by a crystal system because they have crystalline structure. Gemstones are classified into different varieties, species, and groups. They are also characterized in terms of dispersion, hardness, specific gravity, refractive index, luster, fracture, and cleavage. In many references precious stones are diamonds, sapphires, rubies and emeralds. All other stones are considered as semi-precious stones [20]. However, this is a commercial based classification and was a distinction that marketers created years ago which gives the false impression that precious stones are more valuable than semi-precious stones.

The cutting and polishing of gemstones take considerable experience and a good eye, since evaluating a finished gem. Xenoliths samples were subjected to be used as semi-precious stones. For this aim, selected samples were cut and polished to suitable sizes that can be used in different ways. The way of polishing and cutting of xenoliths depend on what shape to make the gem and how many facets it should have. One of the most common roles of cutting is to choose a basic shape for the gemstone. It was considered the shape that the rough or uncut gemstone is already in. This is a very important in our case because some of xenoliths samples have already slight single crystals that have oval or prismatic shape. Oval shape for garnet and olivine would be easier than making them into square or rectangular cut, while the pyroxene like enstatite could be used as prismatic shape. Most common basic cut of gemstones include round, square, oval and triangle. It is very important for the cutting and polishing of the xenoliths is choosing of a shape that will not waste too much of the gem. For this aim most uncut gemstones have oddly shaped so in this case it needs to grind them down. Roughly grinding the outsides of the gem will make it closer to the size and shape we want. Results after cutting and polishing of three samples from xenoliths that could be used as semi-precious stones are shown in Figure 16, Figure 17. Garnet like pyrope and almandine could be considered as semi-precious stone, but due to its weathered properties it is difficult to be appear with suitable color. In general, it has red, orange, brown to pink color, with isometric crystals as shown in Figure 7.

\section{Conclusions}

Xenoliths of different types of minerals are widespread in the northeast Jordanian Plateau Basalt. The basalt has a wide variety of crustal and upper mantle xenoliths that have mostly concentrated in pyroclastic materials. The compositional diversity of the xenoliths suit indicates a heterogeneous upper mantle 


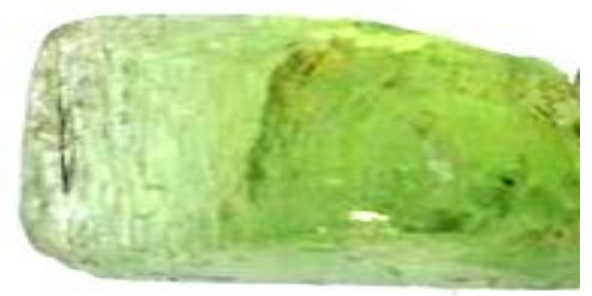

Figure 16. Olivine peridot, a gem variety after cutting and polishing (approximately 20 $\mathrm{mm}$ across).

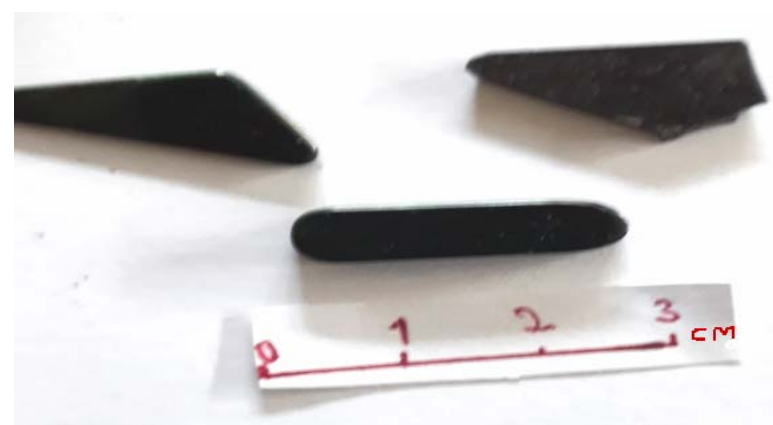

Figure 17. These three specimens are pyroxene, a gem variety of pyroxene. These specimens are approximately $10 \mathrm{~mm}$ across.

beneath the northwestern part of the Arabian plate. The collected samples of xenoliths considered here as semi-precious stones are concentrated and exposed in the Harrat Ash Shaam Basalt Super Group. Their distribution and percentage in the study area varies in all volcanic centers. The high distribution and percentage can be observed in Aritain Volcanic Formation and partially in Hassan, Bishriyya and Ufayhim formations. Different types of xenoliths of olivine, pyroxene, spinel-perioditite and garnet are widespread in the studied area. Olivine is fine-grained and slightly altered to iddingsite with prophyritic to equigranular textures. Plagioclase is the most common phenocryst coexisting with garnet. The pyroxene is found as fine-grained, euhedral to subhedral, fractured and poikilitic. Augite has equigranular shape with brown to pinkish and purple colour. The garnet crystal shows medium grain size, highly fracture, colorless to light color with PPL and dark color with XPL expect light to gray color of fracture filling with other minerals mostly pyroxene. Almandine garnet, up to $3 \mathrm{~mm}$ in size, occurs as a phenocryst in plagioclase. The garnet crystals are euhedral to subhedral and they are rounded to subrounded, mostly garnet highly fractured, and the garent has an intergrowth with pyroxene. Minerals identified by XRD include pyroxene assemblages of calcium-sodium pyroxene as $\mathrm{Ae}=$ Aegirine, $\mathrm{Au}=$ Augite, $\mathrm{Om}=$ Omphacite; and magnesium-iron pyroxene as $\mathrm{En}=$ Enstatite. Garnet group is composed of $\mathrm{Al}=$ Almandine. Traces of $\mathrm{Li}=$ Linnaeite, $\mathrm{Be}=$ Berzelianite, and $\mathrm{Ka}=$ Kanoite are present. The olivine samples consist mainly of $\mathrm{Fo}=$ Forsterite and traces of other minerals as $\mathrm{Az}=$ Azoproite, $\mathrm{La}=$ Laihunite, $\mathrm{Ta}=$ Tassieite were detected by XRD. SEM micrograph images showing anhedral crystals of garnet with highly fracture, and pyroxene surrounding the garnet 
crystal. Electron micrograph images showing kelyphite texture, orthopyroxene with gray lamellae, and plagioclase dark gray background, shows orthopyroxene, plagioclase and nodular spinels adjacent with fibrous texture. Geochemical studies indicate that the bulk chemistry of the xenoliths has relatively similar amounts of major and minor oxides. On the basis for the major elements of $\mathrm{MgO}, \mathrm{Fe}_{2} \mathrm{O}_{3}$ and $\mathrm{CaO}$ content, two samples of the garnet were analyses; $\mathrm{MgO}$ is up to $14.93 \% ; \mathrm{Fe}_{2} \mathrm{O}_{3}$ is up to $16.55 \%$ and $\mathrm{CaO}$ content is up to $5.88 \%$. The chemical composition of three samples of pyroxene show some variation in composition of $\mathrm{SiO}_{2}, \mathrm{CaO}, \mathrm{MgO}$ and $\mathrm{Fe}_{2} \mathrm{O}_{3}$, and a relatively similar content of $\mathrm{CaO}$, $(14.47 \%-16.39 \%)$ and $\mathrm{MgO}(10.53 \%-12.40 \%)$, whereas $\mathrm{Fe}_{2} \mathrm{O}_{3}$ ranges from $12.10 \%$ to $20.77 \%$.

The chemical composition of two samples of olivine showed small variation composition of $\mathrm{SiO}_{2}, \mathrm{CaO}, \mathrm{MgO}$ and $\mathrm{Fe}_{2} \mathrm{O}_{3}$, and a relatively similar content of $\mathrm{CaO}$, up to $2.09 \%$ and $\mathrm{MgO}$ content is up to $41.54 \%$, whereas $\mathrm{Fe}_{2} \mathrm{O}_{3}$ ranges from $12.29 \%$ to $13.27 .77 \%$.

The cutting and polishing of three samples from xenoliths revealed that some of xenoliths could be used as semi-precious stones. Olivine can be found as granular texture or as orthorhombic crystal system. It could be considered as semi-precious stone due to its color (olive green, yellow-green to brownish-green) with vitreous luster and transparent to translucent diaphaneity. Olivine has poor cleavage, brittle with conchoidal fracture.

Pyroxene xenoliths could be considered as semi-precious stone with prismatic and orthorhombic crystal structure. It has brown-green, green and black color. It has good cleavage and vitreous luster, transparent to opaque.

Garnet like pyrope and almandine could be considered as semi-precious stone, but due to its weathered properties it is difficult to be cut. It has red, orange, and brown to pink color, with rounded shape crystals.

\section{Acknowledgements}

This research has been carried out during my Sabbatical leave that granted from Al Hussein Bin Talal University. We would like to thank Amman Arab University for supporting me to follow up this research. We also wish to thank, Prof Mohammed Hwieti (Dean of Faculty of Engineering), Dr Awwad Titi (Head of the Mining and Minerals Department at Al Hussein Bin Talal University). Last but not the least, Eng. Muhammed Abadleh played important role in analyzing of the samples, and Eng. Heba Basem for supporting in preparation of this paper and we would like to acknowledge them.

\section{Conflicts of Interest}

The authors declare no conflicts of interest regarding the publication of this paper.

\section{References}

[1] Bender, F. (1974) Geology of Jordan. Gebrüder Bornträger Verlag, Berlin, 196.

[2] Tarawneh, K., Ibrahim, K. and Rabba, I. (2002) Petrography, Geochemistry and K-Ar 
Geochronology of the Dike Systems (NW-SE) of the Harrat Ash Shaam in Northeast Jordan. Mutah Journal of Natural and Applied Series, 17, 69-87.

[3] Tarawneh, K. (2003) Mineral Occurrences in the Badia Region/NE Jordan. 50 Years University of Mining and Geology "St. Ivan Rilski”. Annual, Part 1, Geology and Geophysics, Vol. 46, Sofia-Bulgaria, 167-170.

[4] Ibrahim, K., Tarawneh, K. and Rabba, I. (2003) Phases of Activity and Geochemistry of Basaltic Dike Systems in Northeast Jordan Parallel to the Red Sea. Journal of Asian Earth Science, 21, 467-472. https://doi.org/10.1016/S1367-9120(02)00075-5

[5] Guba, I. and Mustafa, H. (1988) Structural Control of Young Basaltic Fissure Eruption in the Plateau Basalt Area of the Arabian Plate, Northeastern Jordan. Journal of Volcanology and Geothermal Research, 35, 319-334. https://doi.org/10.1016/0377-0273(88)90026-1

[6] Illani, S., Harlavaa, Y., Tarawneh, K., Rabba, I., Weinberger, R., Ibrahim, K., Peltz, S. and Stttteinitz, G. (2001) New K-Ar Ages of Basalts from the Harat Ash Shaam Volcanic Field in Jordan: Implications for the Span and Duration of the Upper Mantle Upwelling Beneath the Western Arabian Plate. Geology, 29, 171-174. https://doi.org/10.1130/0091-7613(2001)029<0171:NKAAOB>2.0.CO;2

[7] Ibrahim, K. (1993) The Geological Framework for the Harrat Ash Shaam Basaltic Super Group and Its Volcano Tectonic Evolution. Natural Resources Authority, Geological Division, Bulletin 25, Amman.

[8] Al-Malabeh, A. (2004) Discovery of Ultrmafic Xenolith Rich Layer in the Tephra Succession of Jabal Aritain-South Jordan. Mineral Deposits, 12, 23-35.

[9] Nasir, S. and Al-Fuqha, H. (1988) Spinel-Iherzolite Xenoliths from the Aritain Volcano, NE-Jordan. Mineralogy and Petrology, 38, 127-137.

https://doi.org/10.1007/BF01164317

[10] Nasir, S. and Safarjalani, A. (2000) Lithospheric Petrology beneath the Northern Part of the Arabian Plate in Syria: Evidence from Xenoliths in Alkali Basalts. Journal of African Earth Sciences, 30, 149-168. https://doi.org/10.1016/S0899-5362(00)00013-0

[11] Bany Yaseen, I., Al-Hawari, Z. and Diabat, A. (2010) Petrology, Geochemistry, Petrogenesis and Reactivation of Volcanic Tuffs at Dair El-Kahif, NE Jordan. Jordan Journal of Civil Engineering, 4, 336-350.

[12] Bani Yaseen, I. (2014) Petrography and Mineral Chemistry of the Alamanden Grnet, and Implication for Kelyphite Texture in the Miocene Alkali Basaltic Rocks in Northeast Jordan. International Journal of Geosciences, 5, 222-237. https://doi.org/10.4236/ijg.2014.52024

[13] Nasir, S. (1995) Mafic Lower Crustal Xenoliths from the North-Western Part of the Arabian Plate. European Journal of Mineralogy, 7, 217-230. https://doi.org/10.1127/ejm/7/1/0217

[14] Nasir, S. (1992) The Lithosphere beneath the Northwestern Part of the Arabian Plate Jordan: Evidence from Xenoliths and Geophysics. Tectonophysics, 201, 357-370. https://doi.org/10.1016/0040-1951(92)90242-X

[15] Carlson, W. and Johnson, C. (1991) Coronal Reaction Textures in Garnet Amphibolites of the Llano Uplift. American Mineralogist, 76, 756-772.

[16] Sobolev, N. (1977) Deep-Seated Inclusion in Kimberlites and the Problem of the Composition of the Upper Mantle. Edwards, Ann Arbor, 279. https://doi.org/10.1029/SP011

[17] Al-Malabeh, A., Tayel, H. and Mahdi, L. (2009) Geochemical, Petrographic and Mag- 
netic Characteristics of Spinel Lherzolite Mantle Xenoliths from Jabal Remah Volcano, Jordan. American Journal of Applied Sciences, 6, 1308-1312.

https://doi.org/10.3844/ajassp.2009.1308.1312

[18] Thompson, R. (1975) Is Upper-Mantle Phosphorus Contained in Sodic Garnet. Earth and Planetary Science Letters, 26, 417-424. https://doi.org/10.1016/0012-821X(75)90017-5

[19] Thompson, R. (1986) Sources of Basic Magmas. Nature, 319, 448-449. https://doi.org/10.1038/319448a0

[20] Annibale, M., Rodolfe, C. and Giuseppe, L. (1977) Guide to Rocks and Minerals. Simon and Schuter's Inc., New York. 